\title{
Incidentally detected adrenocortical carcinoma in familial adenomatous polyposis: an unusual presentation of a hereditary cancer syndrome
}

\author{
Samarth Agarwal, Ashish Sharma, Deepanshu Sharma, Satyanarayan Sankhwar
}

Department of Urology, King George's Medical University, Lucknow, Uttar Pradesh, India

\section{Correspondence to Dr Ashish Sharma, ashishuc343@gmail.com}

Accepted 20 August 2018

\section{DESCRIPTION}

A 30-year-old woman presented to us with complaints of intermittent bleeding per rectum, vague abdominal pain and altered bowel habits for last 3 months. There was no history of headache, palpitations, diarrhoea, weight loss, skin lesions, haematuria and hypertension. Her grandmother had history of colostomy for acute intestinal obstruction and died of unexplained cause at age of 55 years. Her laboratory investigations were normal. On digital rectal examination, multiple polypoidal firm masses were felt approximately $1-5 \mathrm{~cm}$ from anal verge. On colonoscopy, number of polyps were seen in the colon around 40-50 in number, ranging from few millimetres to largest measuring around $3 \mathrm{~cm}$. These polyps spread over ascending to sigmoid colon and rectum in increasing number. The biopsy from these polyps was suggestive of tubular adenomas. A definitive diagnosis of familial adenomatous polyposis (FAP) was made. FAP is associated with a myriad of presentations, and hence, a thorough work up was done to elicit associated lesions. An upper gastrointestinal endoscopy was performed, which was unremarkable. On slit-lamp examination, discrete flat multiple pigmented lesions were present in retina suggestive of congenital hypertrophy of retinal pigment epithelium (CHRPE). However, the patient did not complain of any eye symptoms.

Further evaluation with contrast-enhanced CT scan (CECT) of abdomen showed multiple

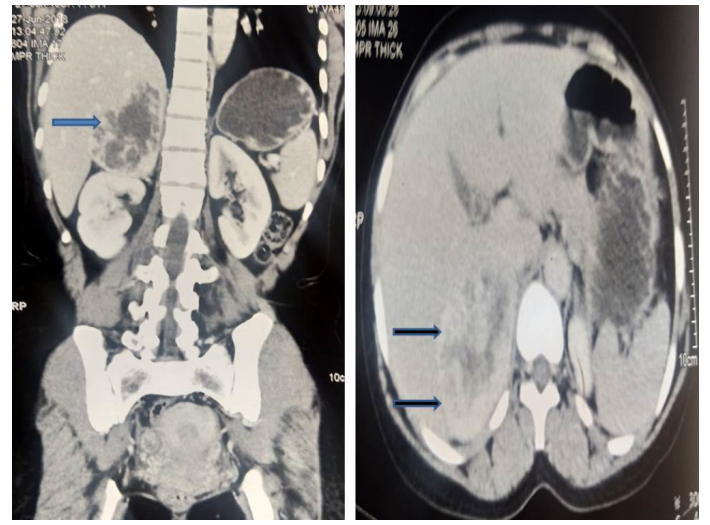

Figure 1 Contrast-enhanced CT scan abdomen (coronal and transverse sections) showing heterogeneously enhancing, well-defined adrenal mass measuring $8.5 \times 8.5 \times 6.5 \mathrm{~cm}$ with areas of necrosis suggestive of localised adrenocortical carcinoma.
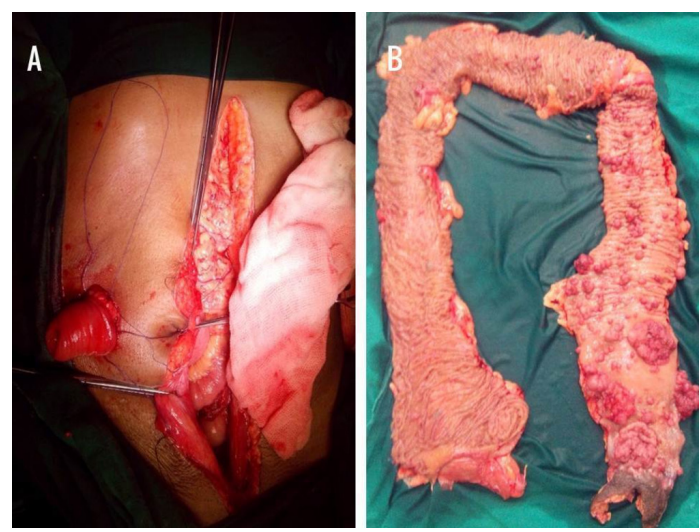

Figure 2 (A) Intraoperative picture showing total proctocoelectomy with permanent end ileostomy. (B) The total proctocoelectomy specimen showing multiple poylpoidal lesions throughout the rectum and sigmoid.

enhancing polypoidal mass lesions (largest of size $3 \times 2 \mathrm{~cm}$ ) throughout the colon and rectum with no evidence of any regional or distant metastasis. To our surprise, CECT also revealed a heterogeneously enhancing, well-defined adrenal mass measuring $8.5 \times 8.5 \times 6.5 \mathrm{~cm}$ with areas of necrosis suggestive of localised adrenocortical carcinoma (ACC) (figure 1). Functional adrenal work-up (serum aldosterone, serum cortisol amd 24 hours urinary metanephrine and normetanephrine) results were within normal range.

After proper counselling, she underwent radical adrenalectomy with total proctocoelectomy with permanent end ileostomy as shown in figure $2 \mathrm{~A}$. The total proctocoelectomy specimen was examined and revealed multiple poylpoidal lesions as shown in figure $2 \mathrm{~B}$. Blood sample of patient was analysed for truncated APC gene product, and in vitro protein synthesis assay was positive. Histopathology and immunohistochemistry (synaptophysin and inhibin) examination revealed high-grade ACC with negative surgical margin with pT3N0M0 staging. The postoperative period was uneventful. She was discharged on postoperative day 8 . She was doing well at 4 weeks follow-up with no significant complains.

The FAP is an autosomal-dominant colorectal cancer syndrome, which is caused by mutation of APC gene on chromosome $5 \mathrm{q} 21$. It is characterised by occurrence of hundreds of adenomatous colorectal polyps and almost inevitable progression to colorectal cancer by the fourth decade of life. Other associated features of FAP include 
upper gastrointestinal polyps, desmoid tumours, CHRPE and other extraintestinal malignancies. Uncommonly, endocrine tumours like parathyroid, pituitary, pancreatic and adrenal neoplasms have been described in these patients. ${ }^{1}$

Due to widespread utilisation of modern imaging modalities like CT and MRI, the detection rates of adrenal incidentalomas has increased during the last decades. About $7 \%$ of patients with FAP or its variants have adrenal masses, as compared with $3 \%$ in general populations. ${ }^{2}$ The biological behaviours of adrenal neoplasm in patients with FAP are comparable with sporadic

\section{Learning points}

- Familial adenomatous polyposis (FAP) is an autosomaldominant colorectal cancer syndrome, which is characterised by occurrence of hundreds of adenomatous colorectal polyps and almost inevitable progression to colorectal cancer by the fourth decade of life.

- The extraintestinal manifestation includes desmoid tumour, retinal lesions and endocrine tumours like parathyroid, pituitary, pancreatic and adrenal neoplasms.

- The clinical presentation and biological behaviours of adrenal neoplasm in FAP is comparable with sporadic cases, and same protocols are followed in these cases.

- Adrenocortical carcinoma is a rare, mostly non-functional neoplasm of adrenal gland with poor prognosis. variety but its required longer follow-up. ${ }^{3}$ Mostly adrenal lesions are non-functional and benign, while functioning adrenal tumour mostly secrets cortisol. These non-functional adrenal tumours are asymptomatic and are usually detected incidentally or at autopsy. ACC is a rare neoplasm of adrenal gland with poor prognosis with incidence of one to two per million populations. The ACC may be associated with Li-Fraumeni, Lynch syndrome, Beckwith-Wideman, MEN type 1 and FAP. There are only few reported cases showing association between FAP and ACC.

Contributors SA: concept, design, supervision, processing, writing manuscript and critical analysis. AS: supervision, processing, writing manuscript and critical analysis. DS: concept, supervision, writing manuscript and critical analysis. SS: concept, supervision, writing manuscript and critical analysis.

Funding The authors have not declared a specific grant for this research from any funding agency in the public, commercial or not-for-profit sectors.

Competing interests None declared.

Patient consent Obtained.

Provenance and peer review Not commissioned; externally peer reviewed.

\section{REFERENCES}

1 Felner El, Taweevisit M, Gow K. Hyperaldosteronism in an adolescent with gardner's syndrome. J Pediatr Surg 2009;44:e21-e23.

2 Smith TG, Clark SK, Katz DE, et al. Adrenal masses are associated with familial adenomatous polyposis. Dis Colon Rectum 2000;43:1739-42.

3 Will OC, Hansmann A, Phillips RK, et al. Adrenal incidentaloma in familial adenomatous polyposis: a long-term follow-up study and schema for management. Dis Colon Rectum 2009; $52: 1637-44$

Copyright 2018 BMJ Publishing Group. All rights reserved. For permission to reuse any of this content visit http://group.bmj.com/group/rights-licensing/permissions.

BMJ Case Report Fellows may re-use this article for personal use and teaching without any further permission.

Become a Fellow of BMJ Case Reports today and you can:

- Submit as many cases as you like

- Enjoy fast sympathetic peer review and rapid publication of accepted articles

- Access all the published articles

- Re-use any of the published material for personal use and teaching without further permission

For information on Institutional Fellowships contact consortiasales@bmjgroup.com

Visit casereports.bmj.com for more articles like this and to become a Fellow 